\title{
Kuraklığın Buğdayın Kök Ağırlığına Etkisi ve Kökün Bazı Fizyolojik Parametrelerle İlișkisi
}

\author{
*irfan ÖZTÜRK¹, Kayıhan Zahit KORKUT² \\ ${ }^{1}$ Trakya Tarımsal Araștırma Enstitüsü, Edirne, Türkiye \\ ${ }^{2}$ Namık Kemal Üni. Ziraat Fak. Tarla Bitkileri Böl. Tekirdağ, Türkiye \\ *Sorumlu yazar e-posta (Corresponding author; e-mail): irfan.ozturk@tarim.gov.tr
}

\begin{abstract}
Öz
Ekmeklik buğdayda kuraklık stresi koșullarında çevresel ve genetik faktörlere göre değișiklikler gözlenebilen kök yapısı önemli faktör olarak değerlendirilmektedir. Araștımada bazı ekmeklik buğday genotiplerinin farklı kuraklık seviyelerindeki kök ağırlıkları ile kök ağırı̆ı̆ının bazı fizyolojik karakterlere olan etkileri incelenmiștir. Araștırma, Trakya Tarımsal Araștırma Enstitüsü deneme alanında 2008-2009 ve 2009-2010 yıllarında yapılmıștır ve 15 genotip kullanılarak; tesadüf blokları bölünmüș parseller deneme desenine göre 3 tekrarlamalı olarak yürütülmüștür. Ana parsellerde beș farklı kuraklık uygulamaları, alt parsellerde genotipler yer almıștır. Araștırmada sapa kalkma döneminden fizyolojik olum dönemine kadar farklı seviyede kuraklık uygulanmıștır. Araștırmada kuraklık stresi uygulaması genotiplerde kök ağırlığını azaltmıștır. Genotiplerde en fazla kök ağırlığı Bereket çeșidinde $(3.618 \mathrm{~g})$ tespit edilmiștir. Kuraklık stresi bitkilerde kök ağırlığını farklı oranlarda etkilemiș olup, en düșük kök ağırlığı (2.815 g) tam kuraklık uygulanan parselde ölçülürken, en fazla kök ağırlığı kuraklık stresi uygulanmayan koșullarda belirlenmiștir. Araștırmada genotiplerde kök ağırlığının artıșı bașaklanma öncesi ve tane dolum döneminde bayrak yapraklarındaki klorofil kapsamını önemli ölçüde artırmıștır. Kök miktarı bütün kuraklık uygulamalarında bitki örtüsü sıcaklığını düșürmüștür. Bitkide kök miktarının genotiplerde bașaklanma, olgunlașma gün sayıları ve tane dolum süresini artırdığı belirlenmiștir. Kök ağırlığı artıșında stoma eni ve boyunda artıș olurken, stoma sayısında azalma olmuștur. Kök ağırlığına genotip ve çevre faktörleri etkili olurken yapraklarda klorofil kapsamında artıș kanopi sıcaklığında azalma olmuștur.
\end{abstract}

Anahtar Kelimeler: Ekmeklik buğday, çeșit, kuraklık, kök ağırlı̆ı, agronomik karakter

\section{Drought Effect on Root Amount and its Relations with Some Physiological Parameters}

\section{Abstract}

The root structure, which is a very important factor in arid conditions in bread wheat, may vary depending on environmental and genetic factors. Root weight of some bread wheat genotypes were investigated under different drought stress condition on the root weight and on some physiological characters. This study was carried out in experimental field of Trakya Agricultural Research Institute in 2008-2009 and 20092010 seasons with 15 bread wheat genotypes in split block design technique with 3 replicate. Five drought applications were the main plots and germplasms were sub-plots. Drought applications were performed from stem elongation stage to physiological maturating stage. Drought stress applications reduced the root weight. The highest root weight was determend in CV Bereket with $3.618 \mathrm{~g}$. Drought stress effected the root weight at different ratios. The lowest root weight was obtained to fully drought condition with $2.815 \mathrm{~g}$ and the highest root weight was determined at non-stress treatment. The increase of root weight in genotypes promote the chlorophyll content in the flag leaves during pre-emergence and grain filling periods. Root weight reduced the canopy temperature under all drought stress applications. It was determined that when the amount of root in the plant enhanced the number of days of heading, maturation days and grain filling periods were increased. While the root weight promoted the stomata width and length, on the contrary it reduced the stomata number. Though the root weigth and environmental factors were affected by genotypes; chlorophyll content in leaves was increased and canopy temperature was decreased.

Keywords: Bread wheat, variety, drought, root weight, agronomic characters 


\section{Giriș}

uraklık, Trakya Bölgesi'nde bazı yıllarda ve özellikle bitkilerde su isteğinin fazla olduğu Nisan ve Mayıs aylarında yağıșın miktarı ve dağııșının yetersiz ve düzensiz olmasından dolayı ortaya çıkmaktadır (Öztürk ve ark., 2016). Genotiplerde değișen koșullara uyum ve adaptasyon kabiliyetinin artırıması, farklı ıslah yöntemleri ile mümkün olmaktadır. Bu nedenle, çoğunlukla kuru tarım yapılan alanlar için kurağa mukavemeti iyi olan çeșitlerin geliștirilmesi ve mevcut alanda üretimi arttırma yollarının araștırılması ıslahçıların temel hedefleri arasındadır (Kalaycı ve ark., 1998). Kurak koșullarda bitkilerde kurağa dayanıklılık ıslah programının önemli bir bölümünü olușturmaktadır. Olgunlașma süresi kısa olan bitkilerdeki erken çiçeklenme özellikle geç dönem kuraklıklarından kaçma açısından ıslaha katkı sağlayan önemli bir karakterdir. Kurak șartlardaki düșük kanopi sıcaklığı bitki bünyesinin yeterli su oranına sahip olduğunu belirtmektedir. Kuraklık stresi olmayan normal koșullarda genotipler arasındaki kanopi sıcaklı̆ında çok az fark olurken, kuraklık stresinin yașandığı koșullarda genotiplerde kanopi sıcaklıkları farkında artıș olmaktadır. Stres koșullarında kanopi sıcaklığı ile verim arasında olumsuz ilișki bulunmaktadır (Blum, 2000). Topraktaki nemli koșullarda kök uzunluğunda genellikle artıș olurken kurak koșullarda azalmalar olmaktadır. Çok dinamik olan bitki kök aksamı, toprakta yağıșla birlikte artan nemli koșullarda kök dallarında yenilenme olmakta ve bu durum bitkiyi kuraktan koruyan önemli bir faktör olarak ortaya çıkmaktadır (Blum, 2009). Çevresel ve genetik faktörler arasındaki etkileșim kuvvetli kök sisteminin gelișimini belirler (Passioura, 1983). Su stresi bitkilerde kök özelliklerini önemli düzeyde etkilemekte ve su stresinin șiddetine bağlı olarak kök uzunluğu ve kök kuru madde oranı gibi karakterlerde düșme olmaktadır (Adda ve ark., 2005). Ancak genotiplerde sürgün ve kök uzunluğunun çevre koşullarına göre genetik varyasyona daha fazla bağlı olmaktadır (Dhanda ve ark., 2004). Kurağa dayanıklı genotipler hassas genotiplere göre bitki tacı bölgesinde genellikle daha fazla köke sahiptir. Ayrıca kurağa dayanıklı genotipler uzun kök yapısına gerek duymamaktadır. Kurağa hassas genotiplerin kökleri daha fazla absorbsiyon yüzey alanına sahiptir. Kök derinliği, toplam kök uzunluğu, nispi absorbsiyon yüzey alanı, kök sayısı, kök yayılımı ve kök yoğunluğunda genotipler arasında önemli farklılıklar bulunmaktadır (Kinyua ve ark., 2006). Akdeniz koșullarında, orta derinlikteki topraklarda daha yüksek kök uzunluğu muhtemelen artan su alımı için derin kök uzunluğu daha önemli olmaktadır (Gregory ve ark., 2009). Buğday kök sisteminde, yüzey katmanlarda așırı kök uzunluğunun ve derinlikte yetersiz kök uzunlukları olması durumunda, özellikle toprak altı suyuna erișmesi uygun olmayabilir. Bitkilerin topraktaki su ve azot kaynaklarından yararlanması için yeterli kök uzunluğu 0.1 ila $1 \mathrm{~cm} / \mathrm{cm}^{2}$ 'dir (Van Noordwijk, 1983). Modern buğday çeşitlerinde pek çok toprak tabakasındaki kök uzunluğu, yoğunluğu, topraktaki suyun ve önemli besinlerin alınması için gereken miktarın üzerine çıkmaktadır. Buğday için kök uzunluğu ve yoğunluğu, sürüm katmanında 3 ila $6 \mathrm{~cm} / \mathrm{cm}^{3}$ arasında, $40 \mathrm{~cm}$ 'nin altında bulunan $1 \mathrm{~cm} / \mathrm{cm}^{3}$ 'ün altında bulunmuștur (Hoad ve ark., 2004).

Dünyada buğday üretimi yapılan alanlarda su stresi çok önemli iklim değișkenliklerindendir (Heichel, 1971). Kuraklık ile bașa çıkabilmek amacıyla bitkilerde $\mathrm{CO}_{2}$ alımı için stomalar açılır, kurak koșullar süresince yaprakların su kaybını en aza indirmek için stomalarını kapatırlar (Elizabeth ve Alistair, 2007). Bitki bünyesine alınan suyun $\% 95$ 'ten fazlası terleme ile kaybedildiği tahmin edilmektedir (Jianwu ve ark., 2006; Blum, 2009). Bu nedenle bitkilerde stoma yapısı ve davranıșı kuraklıkla ilișkili olarak önemli rol oynamaktadır.

Bitkide kökler terleme ile kaybedilen suyun karșılanması için ana unsurdur. Kök derinliği (veya maksimum uzunluk) ve kök uzunluğu yoğunluğu kökün iki temel unsurudur. Kuraklığa dayanıklılıkta birinci etken köktür. Çok sığ toprak derinliklerinde yanal köklerin gelişimi, az miktarda aralıklı olarak düșen yağıștan yararlanmak bakımından önemli rol oynayabilir (Blum, 2009).

Trakya Bölgesi'nde toplam yağıș miktarı yeterli olmasına rağmen buğdayda yağıș isteğinin fazla olduğu bitkide sapa kalkma döneminden tane dolum dönemleri arası yağıș dağılımının düzensiz olması ve Mayıs 
ayındaki yüksek sıcaklık ile birlikte bitkide kuraklık stresine bağlı olarak verim ve kalite düșüklüğü olabilmektedir. Bu durum bölgede toprak organik maddesinin düșük olmasından dolayı özellikle kumsal yapılı topraklarda daha belirgin olarak ortaya çıkmaktadır. Araștırmada farklı bitki gelișme dönemlerindeki kuraklık uygulamalarının genotiplerde ve farklı seviyede kuraklık uygulamalarında kök miktarı ile kök ağırlığının bazı fizyolojik karakterlerle ilișkisi incelenmiștir. Araștırmada incelenen genotiplerden kurağa dayanıklı veya toleranslı olanların belirlenmesi ile kurak koșullarda önemli olan fizyolojojik parametrelerin belirlenmesi araștırmanın amaçlarındandır.

\section{Materyal ve Yöntem}

Araștırma Trakya Tarımsal Araștırma Enstitüsü deneme tarlasında 2008-2009 ve 2009-2010 yıllarında 2 yıl süreyle yürütülmüștür. Denemede toplam 15 ekmeklik buğday genotipi tesadüf bloklarında bölünmüș parseller deneme desenine göre 3 tekrarlamalı olarak ekilmiștir. Araștırmada kuraklığa duyarlığı farklı olan ve kurak koșullarda farklı tepki veren; Kate A-1, Gelibolu, Pehlivan, Tekirdağ, Selimiye, Aldane, Bereket Flamura-85 ve Golia çeșitleri ile BBVD7, ÖVD26-07, ÖVD2/21-07, ÖVD2/27-07, EBVD24-07 ve BBVD21-07 hatları kullanılmıștır. Denemede 5 ana parsel yer almıș olup, ana parselleri kuraklık uygulamaları, alt parselleri genotipler olușturmuștur. Deneme 6 sıralı ve sıra arası $17 \mathrm{~cm}$ ve parsel alanı $6 \mathrm{~m}^{2}$ olan parsellere metrekareye 500 tane tohum düșecek șekilde deneme ekim makinesi ile ekilmiștir.

Kuraklık uygulanacak parsellere portatif seralar kurulmuștur. Bu seraların üzeri yağmurun yağacağı dönemlerde yağmurun düșmemesi için șeffaf naylon örtülerle açılır-kapanır sistem ile kuraklık stresi olușturulmuștur. Araștırmada ana parsellerde yapılan uygulamalar; birinci uygulamada (KS1) Zadoks skalasına göre GS31-51 arasında (sapa kalkma dönemi ile bașaklanma dönemi arası) kuraklık uygulanıp, bu dönemden sonra tane dolum döneminde günlük buharlașma su miktarına göre bir defa sulama yapılmıștır (Zadoks ve ark., 1974). İkinci uygulamada (KS2) GS51-94 döneminde (bașaklanma dönemi ile tane dolum dönemi sonu) kuraklık uygulanmıștır. KS2 uygulamasında sapa kalkma ile bașaklanma dönemleri arasında günlük buharlașma su miktarına göre bir defa sulama yapılmıștır. Üçüncü uygulamada (KS3) kuraklık stresi uygulanmamıș olup sapa kalkma, bașaklanma ve tane dolum dönemlerinde olmak üzere günlük buharlașma su miktarına göre 3 defa sulama yapılmıștır. Dördüncü uygulama (KS4; Doğal) doğal parsel olup, beșinci uygulamada (KS5) GS31-94 dönemi (sapa kalkma ile tam olum dönemi) arasında tam kuraklık uygulaması yapılmıștır.

Araștırmada farklı bitki gelișme dönemlerindeki kuraklığın kök ağırlığına etkisi ile kök ağırlığının genotiplerde bazı morfolojik, fizyolojik özellikler ile ilișkisi incelenmiștir. Araștırmada; kök ağırlığı, bitki örtüsü sıcaklığı, klorofil kapsamı, bașaklanma ve olgunlașma gün sayıları, tane dolum süresi, stoma sayısı, stoma eni ve boyu, mumsuluk oranı ile kök ağırlığının bu karakterler ile ilișkisi incelenmiștir. Araștırmada infrared termometre ile bitki örtüsü sıcaklığı (Amani ve ark., 1996; Ayeneh ve ark., 2002) gebeleșme, bașaklanma ve tane dolum dönemi olmak üzere üç farklı bitki gelișme döneminde ölçümü yapılmıștır. Genotiplerde bayrak yaprakta klorofil ölçümü SPAD502 klorofilmetre (Babar ve ark., 2006a; Fischer, 2007) ile bitkilerin gebeleșme (GS49) bașaklanma (GS60) ve tane dolum dönemi (GS75) olmak üzere üç farklı gelișme döneminde ölçüm yapılmıștır. Yaprağın klorofil kapsamının belirlenmesinde en uygun ölçüm zamanı klorofilin en yoğun olduğu çiçeklenme sonrası dönemdir (Fischer 2001). Genotiplerde bașaklanma gün sayısı parselde bașakların \%50'sinin bașaklandığı, olgunlașma gün sayısı parselde bitkilerin tamamen sarardığı süre dikkate alınarak belirlenmiștir. Tane dolum süresi bașaklanma ile fizyolojik olum dönemleri arasındaki süre dikkate alınmıștır. Mumsuluk oranları için bașaklanma döneminde bitkideki mumsuluk oranına göre 0-9 skalası kullanılarak belirlenmiștir. Stoma sayısı bașaklanma döneminde bayrak yapraktan alınan örneklerde 4x100 büyüklüğündeki mikroskop ile sayım yapılarak belirlenmiștir. Genotiplerde bitki kök örnekleri ekimde sıra arası mesafe 17 cm olmasından dolayı, $17 \mathrm{~cm}$ çapında ve 50 $\mathrm{cm}$ derinliğinde silindirik metal kaplar ile hasat sonrası her parselden çıkarılmıştır. 
Çizelge 1. 2008-2009 ve 2009-2010 yıllarında ölçülen toplam yağıș, ortalama nem en düșük ve en yüksek sıcaklık ve ortalama sıcaklık verileri

Table 1. Total rainfall, mean humidity, lowest and highest temperature and mean temperature scored in 2008-2009 and in 2009-2010 growing period

\begin{tabular}{|c|c|c|c|c|c|c|c|}
\hline \multirow{2}{*}{ Aylar } & \multirow{2}{*}{$\begin{array}{l}\text { Uzun Yıllar } \\
\text { Yağıș (mm) }\end{array}$} & \multirow{2}{*}{ Yillar } & \multirow{2}{*}{$\begin{array}{l}\text { Aylık Toplam } \\
\text { Yağıș (mm) }\end{array}$} & \multirow{2}{*}{$\begin{array}{c}\text { Aylık } \\
\text { Nem (\%) }\end{array}$} & \multicolumn{3}{|c|}{ Sıcaklık $\left({ }^{\circ} \mathrm{C}\right)$} \\
\hline & & & & & En Düșük & En Yüksek & Ortalama \\
\hline \multirow[t]{2}{*}{ Ekim } & 52.9 & $2008-2009$ & 17.0 & 72.6 & 3.5 & 26.5 & 14.9 \\
\hline & & $2009-2010$ & 112.6 & 82.3 & 2.9 & 28.9 & 15.1 \\
\hline \multirow[t]{2}{*}{ Kasım } & 72.4 & 2008-2009 & 29.2 & 77.8 & -2.0 & 18.3 & 15.3 \\
\hline & & $2009-2010$ & 51.7 & 89.7 & -1.7 & 22.7 & 9.7 \\
\hline \multirow[t]{2}{*}{ Aralık } & 61.7 & 2008-2009 & 35.6 & 82.2 & -6.9 & 20.4 & 6.4 \\
\hline & & $2009-2010$ & 93.4 & 89.7 & -2.1 & 19.6 & 7.3 \\
\hline \multirow[t]{2}{*}{ Ocak } & 48.1 & 2008-2009 & 48.6 & 87.8 & -11.2 & 17.5 & 6.5 \\
\hline & & $2009-2010$ & 59.6 & 85.2 & -16.3 & 20.3 & 2.5 \\
\hline \multirow[t]{2}{*}{ Șubat } & 46.9 & 2008-2009 & 83.2 & 81.3 & 0.1 & 13.5 & 5.2 \\
\hline & & 2009-2010 & 107.0 & 88.1 & -4.8 & 20.3 & 5.9 \\
\hline \multirow[t]{2}{*}{ Mart } & 52.2 & 2008-2009 & 44.1 & 77.5 & 3.0 & 17.9 & 7.8 \\
\hline & & $2009-2010$ & 47.6 & 81.9 & -3.1 & 22.2 & 7.7 \\
\hline \multirow[t]{2}{*}{ Nisan } & 51.0 & 2008-2009 & 15.8 & 68.8 & -0.4 & 25.9 & 12.3 \\
\hline & & $2009-2010$ & 17.8 & 76.0 & 0.9 & 24.9 & 12.7 \\
\hline \multirow[t]{2}{*}{ Mayıs } & 56.0 & 2008-2009 & 27.7 & 66.1 & 7.5 & 32.1 & 19.1 \\
\hline & & $2009-2010$ & 16.0 & 68.6 & 3.3 & 33.6 & 18.1 \\
\hline \multirow[t]{4}{*}{ Haziran } & 41.5 & $2008-2009$ & 25.9 & 62.5 & 9.3 & 36.4 & 22.6 \\
\hline & & $2009-2010$ & 30.8 & 72.3 & 12.0 & 38.7 & 22.5 \\
\hline & & 2008-2009 & 327.1 & 75.2 & -11.2 & 36.4 & 12.2 \\
\hline & & 2009-2010 & 536.5 & 81.5 & -16.3 & 38.7 & 11.3 \\
\hline \multirow[t]{2}{*}{$\begin{array}{l}\text { Toplam } \\
\text { (Uzun yıl) }\end{array}$} & 482.7 & Toplam & 431.8 & & & & \\
\hline & & Ortalama & & 78.4 & -1.7 & 25.7 & 11.8 \\
\hline
\end{tabular}

Araștırmada elde edilen verilerin değerlendirilmesi ve ortalamalar arasındaki farklılık en küçük önemli fark (AÖF) testi ile $(\mathrm{p}<0.01$ ve $\mathrm{p}<0.05)$ incelenmiștir (Gomez ve Gomez, 1984; Kalaycı, 2005).

\section{Bulgular ve Tartıșma}

\section{Kök ağırlığı:}

Araștırmada kök ağırlığına göre genotipler ve uygulamalar ile bunların arasındaki interaksiyon her iki yılda da 0.01 seviyesinde çok önemli bulunmuștur. Bitki kök aksamı kurağa dayanıklılıkta çok önemli bir karakter olmasından dolayı birçok araștırıcı tarafından incelenen bir karakter olmuștur. Kurak koșullarda bitkilerin kök ağırlığında azalma olduğu görülürken, sulama koșullarının kök ağırlığını artırdığı tespit edilmiștir. Beș farklı seviyede kuraklığın incelendiği araștırmada $3.496 \mathrm{~g}$ ile en fazla kök ağırlığı kuraklık stresi uygulanmayan KS3 parselinde ölçülürken, sapa kalkma döneminden bașaklanma dönemine kadar kuraklık stresi uygulanmayan KS2 parselde $3.455 \mathrm{~g}$ olarak belirlenmiștir. Uygulama konularında en düșük kök ağırlığı $2.815 \mathrm{~g}$ ile sapa kalkma döneminden fizyolojik olum dönemine kadar kuraklık uygulanan KS5 parselde belirlenmiștir. Bu sonuçlara göre kuraklık stresinin bitki kök ağırlığını azalttığı ve sulama koșullarının ise bitkilerde kök aksamını artırdığı belirlenmiștir. Genotiplerde 3.618 g ile en fazla kök ağırlığı Bereket çeșidinde ölçülmüștür. En az kök ağırlıkları $2.740 \mathrm{~g}$ ile Tekirdağ çeșidinde ölçülmüștür. Ekmeklik buğdayda kök özelliklerinde genetik farklılık olduğu, bu farklılık derin kök sistemi olușturma yeteneğine göre buğday genotipleri arasındaki 
Çizelge 2. Farklı kuraklık uygulamalarına göre ortalama kök miktarı ve diğer fizyolojik parametreler

Table 2. Average root weight and physiological parameters based on various droughts treatment

\begin{tabular}{lllllllll}
\hline Uygulama & KÖK & CTH & CHH & STS & MUM & BGS & OGS & TDS \\
\hline KS1 & $2.861 \mathrm{bc}$ & $28.07 \mathrm{~b}$ & $50.72 \mathrm{c}$ & $10.97 \mathrm{c}$ & $4.07 \mathrm{~b}$ & $163.5 \mathrm{~d}$ & $201.3 \mathrm{~d}$ & $33.09 \mathrm{~b}$ \\
$\mathrm{KS} 2$ & $3.455 \mathrm{a}$ & $21.43 \mathrm{~d}$ & $51.98 \mathrm{ab}$ & $10.74 \mathrm{~cd}$ & $3.80 \mathrm{c}$ & $166.6 \mathrm{~b}$ & $202.9 \mathrm{~b}$ & $32.12 \mathrm{c}$ \\
$\mathrm{KS} 3$ & $3.496 \mathrm{a}$ & $19.96 \mathrm{e}$ & $52.21 \mathrm{a}$ & $10.58 \mathrm{~d}$ & $3.33 \mathrm{~d}$ & $167.2 \mathrm{a}$ & $206.7 \mathrm{a}$ & $34.88 \mathrm{a}$ \\
$\mathrm{KS} 4$ & $2.937 \mathrm{~b}$ & $22.59 \mathrm{c}$ & $52.34 \mathrm{a}$ & $11.33 \mathrm{~b}$ & $3.67 \mathrm{c}$ & $165.2 \mathrm{c}$ & $201.8 \mathrm{c}$ & $32.00 \mathrm{c}$ \\
KS5 & $2.815 \mathrm{c}$ & $29.21 \mathrm{a}$ & $51.46 \mathrm{~b}$ & $11.96 \mathrm{a}$ & $4.40 \mathrm{a}$ & $162.6 \mathrm{e}$ & $199.1 \mathrm{e}$ & $31.28 \mathrm{~d}$ \\
\hline Ortalama & 3.113 & 24.25 & 51.74 & 11.12 & 3.85 & 165.0 & 202.4 & 32.67 \\
\hline A.Ö.F(0.05) & 0.11 & 0.33 & 0.55 & 0.30 & 0.20 & 0.29 & 0.28 & 0.37 \\
F & $* *$ & $* *$ & $* *$ & $* *$ & $* *$ & $* *$ & $*$ & $*$
\end{tabular}

Not: **P<0.01; *P<0.05; KS: Kuraklık stresi, KÖK: kök ağırlı̆̆ı (g), CTH: Bașaklanma dönemi kanopi sıcaklığı, CHH: Bașaklanma dönemi klorofil, STS: Stoma sayısı, MUM: Mumsuluk oranı (1-9), BGS: Bașaklanma gün sayısı, OGS: Olgunlașma gün sayıs, TDS: Tane dolum süresi

Note: ${ }^{* *} P<0.01{ }^{*} P<0.05 ; \mathrm{KS}$ : Drought stress, KÖK: root weight (g), CTH: Canopy temperature at heading, CHH: Chlorophyll at heading, STS: Stomata number, MUM: Gloucousity (1-9), BGS: Days of heading, OGS: Days of maturity, TDS: Days of grain filling

farklılıklar olabileceği (Siddique ve ark.,1990) belirlenmiștir. Ayrıca normal yağıș koșulları altında, kurak yıllarda buğday kök uzunluğunun daha yüksek olduğu bulunmuștur (Hamblin ve ark., 1990).

Genotiplerdesustresiköközellikleriniönemli düzeyde etkilemekte olup su stresinin șiddetine bağlı olarak bazı kök özelliklerini düșürmekte (Adda ve ark. 2005) olduğunu, kurak koșullar genellikle bitki kök gelișimine engel olmakta ve dolayısı ile nemli toprak koșullarında kök uzunluğunda artıș olurken kurak koșullarda azalmalar olduğu (Blum, 2009), kök derinliği, kök yayılımı ve yoğunluğunda genotipler arasında önemli farklılıklar olduğunu (Kinyua ve ark. 2006) açıklayan araștırmacıların sonucu bu çalıșmada da görülmüștür. Araștırmada kanopi sıcaklığı ve klorofil kapsamı bitki gelișmesinin bașaklanma öncesi, bașaklanma ve tane dolum dönemi olmak üzere üç farklı bitki gelișme döneminde ölçülmüștür. Ölçüm yapılan üç bitki gelișme döneminde bütün uygulamalarda kurak koșullarda bitki örtüsü sıcaklığında artıș olmuștur (Çizelge 2).

\section{Kanopi sıcaklığı:}

Araștırmada kanopi sıcaklığına göre genotipler ve uygulamalar arasındaki interaksiyon 0.01 seviyesinde çok önemli bulunmuștur. Araștırmada bașaklanma öncesi dönemde yapılan ölçümde ortalama kanopi sıcaklı̆̆ı $19.47{ }^{\circ} \mathrm{C}$ olmuștur. Bu dönemde en yüksek sıcaklık $21.65^{\circ} \mathrm{C}$ ile bașaklanma öncesi dönemde kuraklık uygulanan (KS1) parsellerde, en düșük sıcaklık ise 17.21 derece ile kuraklık stresi uygulanmayan (KS3) parsellerde ölçülmüștür. Bașaklanma döneminden itibaren parsellerde kuraklık stresinin etkisi artmaya bașlamıș bu nedenle uygulamalar arasında kanopi sıcaklığı farkında artıș olmuștur. Bașaklanma döneminde yapılan ölçümde ise en yüksek sıcaklık $29.21^{\circ} \mathrm{C}$ ile tam kuraklık uygulanan (KS5) ana parsellerde, en düșük sıcaklık ise $19.96{ }^{\circ} \mathrm{C}$ ile kuraklık stresi uygulanmayan (KS3) parsellere ölçülmüștür (Çizelge 2). Tane dolum döneminde ölçüm yapılan kanopi sıcaklığı önceki bitki gelișme dönemlerindeki sonuca paralel olarak en yüksek sıcaklık yine tam kuraklık uygulamalarında en düșük sıcaklık ise kuraklık stresi uygulanmayan koșullarda saptanmıștır.

\section{Klorofil kapsamı:}

Araștırmada bayrak yaprakta klorofil miktarı üç farklı bitki gelișme döneminde ölçülmüș olup kurak koșulların klorofil miktarını azalttığı görülmüștür. Bașaklanma öncesi dönemde kuraklık stresinin etkisi düșük olduğu için uygulama konuları ve genotipler arasındaki ilișki önemsiz olmuștur. Bașaklanma ve tane dolum dönemlerinde kuraklık uygulamaları ve genotipler arasındaki ilișki çok önemli bulunmuștur. Ayrıca bitkilerde bașaklanma dönemine kadar klorofil miktarında artıș olduğu ve daha sonra azalmaya bașladığı görülmüștür (Çizelge 2). Kuraklık uygulamalarına göre en yüksek klorofil miktarı bașaklanma döneminde yapılan ölçümde belirlenmiștir. Tane dolum 
döneminde ise genotiplerde klorofil miktarının düștüğü görülmüștür. Genotiplere göre en fazla klorofil miktarı bașaklanma döneminde 55.23 ile ÖVD2/27-07 hattında ölçülürken, bunu BBVD7 (53.91) ve Gelibolu (53.62) çeșitleri takip etmiștir (Çizelge 3).

\section{Stoma özellikleri:}

Stoma eni, stoma uzunluğu ve sayısına göre yapılan değerlendirmede genotip ve uygulama konularına göre farklılıklar olduğu belirlenmiștir (Çizelge 2 ve 4). Genotiplerde kurak koșullarda stoma sayısının arttığı buna göre tam kuraklığın uygulandığı ana parselde 11.96 ile en fazla stoma sayısı saptanmıștır. En az stoma 10.58 ile kuraklık stresinin uygulanmadığı koșullarda saptanmıștır. Genotiplerde kurak koșullarda stoma sayısında artış olurken, stoma eni ve boyunun daha kısa olduğu, kuraklı̆ın stoma hacmini olumsuz yönde etkilediği belirlenmiștir. Araștırmada en uzun $(52.23 \mu)$ ve en geniș $(26.93 \mu)$ stoma kuraklık stresi uygulanmayan (KS3) koșullarda ölçülmüștür.
Ekmeklik buğdayda kurağa dayanıklııkta birçok morfolojik ve fizyolojik karakterler farklı etkiye sahiptir. Kuraklığa toleransta bitkilerde bazı morfolojik ve fizyolojik özellikler, stoma hacmi ve sayısı, stomanın açık veya kapalı olması, mumsuluğu, kök uzunluğu, kök yoğunluğu ve kuru ağırlığı gibi özellikler kuraklıkta değerlendirilmesi gereken önemli karakterlerdir (Dencic ve ark., 2000).

\section{Mumsuluk:}

Araștırmada genotipler ve uygulama konuları arasında mumsuluk oranı yönünden önemli farklılık belirlenmiștir. Kurak koșulların genotiplerde mumsuluğu arttırdığı tespit edilmiștir. Genotip x kuraklık uygulamaları birlikte değerlendirildiğinde mumsuluğun çeșitlerde genetik yapıya bağlı olduğu gibi çevre koșullarından da etkilendiği tespit edilmiștir. Yapılan araștırmada genotiplere göre karșılaștırma yapıldığında mumsuluk ile tane verimi arasında olumlu ilișki tespit edilirken, uygulama konularına göre yapılan karșılaștırmada kurak koșullarda mumsuluğun

Çizelge 3. Genotiplere göre ortalama kök ağırlığı ve bazı fizyolojik parametreler

Table 3. Average root weight and some physiological parameters based on genotypes

\begin{tabular}{|c|c|c|c|c|c|c|c|c|c|}
\hline No & Genotipler & KÖK & СТH & $\mathrm{CHH}$ & STS & MUM & BGS & OGS & TDS \\
\hline 1 & Kate A-1 & $2.922 \mathrm{de}$ & $23.78 \mathrm{e}$ & $52.53 \mathrm{de}$ & $11.29 \mathrm{~cd}$ & $6.1 \mathrm{~b}$ & $163.3 \mathrm{~g}$ & $200.9 \mathrm{ght}$ & 32.9 def \\
\hline 2 & Gelibolu & $3.128 \mathrm{~cd}$ & 24.12 cde & $53.62 \mathrm{bc}$ & $11.42 \mathrm{~cd}$ & $3.7 \mathrm{~d}$ & $164.2 \mathrm{f}$ & $202.7 \mathrm{e}$ & $33.9 \mathrm{bc}$ \\
\hline 3 & Pehlivan & $3.250 \mathrm{bc}$ & 24.14 cde & 49.16 jk & $11.21 \mathrm{~cd}$ & $5.9 \mathrm{~b}$ & $166.0 \mathrm{~d}$ & $201.3 \mathrm{~g}$ & $31.4 \mathrm{~g}$ \\
\hline 4 & Tekirdağ & $2.740 \mathrm{e}$ & $24.91 \mathrm{a}$ & $52.59 \mathrm{cde}$ & 10.90 def & $1.0 \mathrm{I}$ & $163.2 \mathrm{~g}$ & $201.0 \mathrm{ghı}$ & $33.1 \mathrm{cde}$ \\
\hline 5 & Selimiye & $2.967 \mathrm{de}$ & $24.30 \mathrm{bcd}$ & 49.98 ij & $11.62 \mathrm{bc}$ & $5.0 \mathrm{c}$ & $164.0 \mathrm{f}$ & $201.1 \mathrm{gh}$ & $33.0 \mathrm{def}$ \\
\hline 6 & Aldane & $2.813 \mathrm{e}$ & $24.47 a b c$ & $51.39 \mathrm{fg}$ & $10.31 \mathrm{gh}$ & $5.1 \mathrm{c}$ & $162.4 \mathrm{~h}$ & 200.5 I & $33.6 \mathrm{bcd}$ \\
\hline 7 & Flamura-85 & $2.953 \mathrm{de}$ & $24.38 \mathrm{bcd}$ & $53.01 \mathrm{bcd}$ & $10.87 \mathrm{~d}-\mathrm{g}$ & $2.8 \mathrm{e}$ & $165.6 \mathrm{de}$ & 202.3 ef & $32.2 \mathrm{fg}$ \\
\hline 8 & Golia & $2.937 \mathrm{de}$ & $24.70 a b$ & 50.24 hı & $13.09 \mathrm{a}$ & $1.2 \mathrm{hl}$ & 157.7 । & $199.0 \mathrm{j}$ & $34.8 \mathrm{a}$ \\
\hline 9 & BBVD7 & $3.480 \mathrm{ab}$ & $24.20 \mathrm{~b}-\mathrm{e}$ & $53.91 \mathrm{~b}$ & $11.02 \mathrm{de}$ & $8.9 \mathrm{a}$ & $162.6 \mathrm{~h}$ & 200.6 hı & $33.7 \mathrm{bcd}$ \\
\hline 10 & Bereket & $3.618 \mathrm{a}$ & $23.92 \mathrm{de}$ & 51.79 ef & $10.18 \mathrm{~h}$ & $5.1 \mathrm{c}$ & $165.1 \mathrm{e}$ & $202.1 \mathrm{f}$ & 32.7 ef \\
\hline 11 & ÖVD26-07 & $2.788 \mathrm{e}$ & $24.43 \mathrm{a}-\mathrm{d}$ & $50.75 \mathrm{ghı}$ & 10.50 e-h & $2.0 \mathrm{fg}$ & $163.4 \mathrm{~g}$ & 202.6 ef & $34.0 \mathrm{ab}$ \\
\hline 12 & ÖVD2/21-07 & $3.483 \mathrm{ab}$ & $23.94 \mathrm{de}$ & $51.16 \mathrm{fgh}$ & 10.54 e-h & $1.5 \mathrm{gh}$ & $168.3 \mathrm{c}$ & 205.4 b & 32.6 ef \\
\hline 13 & ÖVD2/27-07 & $3.121 \mathrm{~cd}$ & $24.00 \mathrm{cde}$ & $55.23 \mathrm{a}$ & $10.41 \mathrm{fgh}$ & $6.3 \mathrm{~b}$ & $164.2 \mathrm{f}$ & $203.4 d$ & $34.3 \mathrm{ab}$ \\
\hline 14 & EBVD24-07 & $3.103 \mathrm{~cd}$ & 24.02 cde & 52.01 def & $11.31 \mathrm{~cd}$ & $1.1 \mathrm{hl}$ & 170.6 b & $204.5 c$ & $29.1 \mathrm{~h}$ \\
\hline 15 & BBVD21-07 & $3.394 \mathrm{ab}$ & $24.48 \mathrm{abc}$ & $48.80 \mathrm{k}$ & $12.08 \mathrm{~b}$ & $2.1 \mathrm{f}$ & $175.0 \mathrm{a}$ & $208.0 \mathrm{a}$ & $28.8 \mathrm{~h}$ \\
\hline \multicolumn{2}{|c|}{ Ortalama } & 3.113 & 24.25 & 51.74 & 11.12 & 3.85 & 165.0 & 202.4 & 32.67 \\
\hline \multicolumn{2}{|c|}{ A.Ö.F (0.05) } & 0.23 & 0.52 & 1.03 & 0.58 & 0.50 & 0.47 & 0.54 & 0.85 \\
\hline \multicolumn{2}{|l|}{$F$} & $* *$ & $\star \star$ & $\star \star$ & ** & $* *$ & $\star *$ & $\star \star$ & $\star \star$ \\
\hline
\end{tabular}

Not: ${ }^{* *} \mathrm{P}<0.01,{ }^{*} \mathrm{P}<0.05$; KÖK: kök ağılığı (g), CTH: Bașaklanma dönemi kanopi sıcaklığı, CHH: Bașaklanma dönemi klorofil, STS: Stoma sayıSı, MUM: Mumsuluk oranı (1-9), BGS: Bașaklanma gün sayıSı, OGS: Olgunlașma gün sayıs, TDS: Tane dolum süresi, Note: ${ }^{*} P<0.01,{ }^{*} P<0.05 ; K S$ : Drought stress, KÖK: root weight (g), CTH: Canopy temperature at heading, CHH: Chlorophyll at heading, STS: Stomata number, MUM: Gloucousity (1-9), BGS: Days of heading, OGS: Days of maturity, TDS: Days of grain filling 


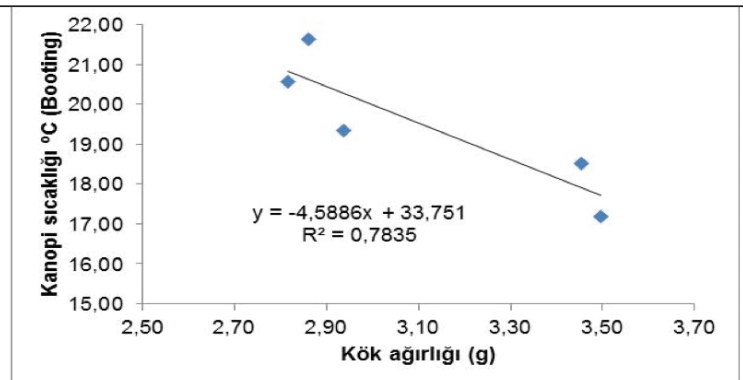

Kök ağırıı̆ı ve kanopi sıcaklığı $\left({ }^{\circ} \mathrm{C}\right)$ (Sapa kalkma dönem) Root weight and canopy temperature (shooting stage)

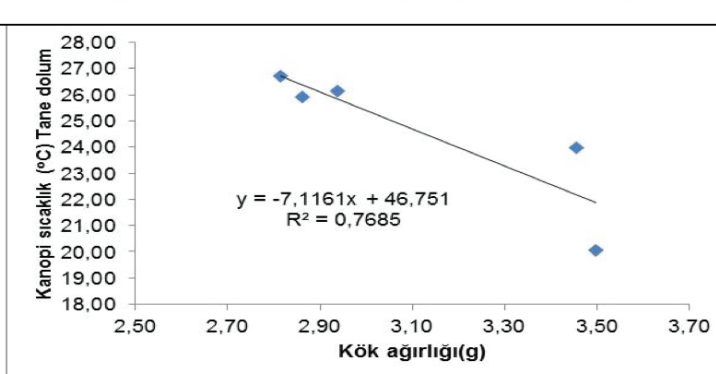

Kök ağırlığı ve kanopi sıcaklığı ( ${ }^{\circ} \mathrm{C}$ ) (Tane dolum dönemi) Root weight and canopy temperature (grain filling stage)

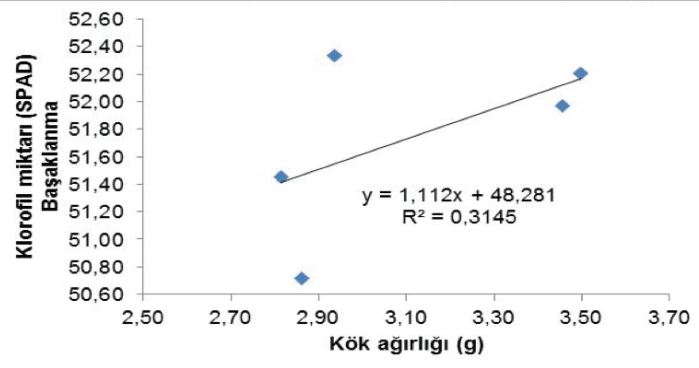

Kök ağırlığı ve klorofil (SPAD) (Başaklanma) Root weight and chlorophyll (heading stage)

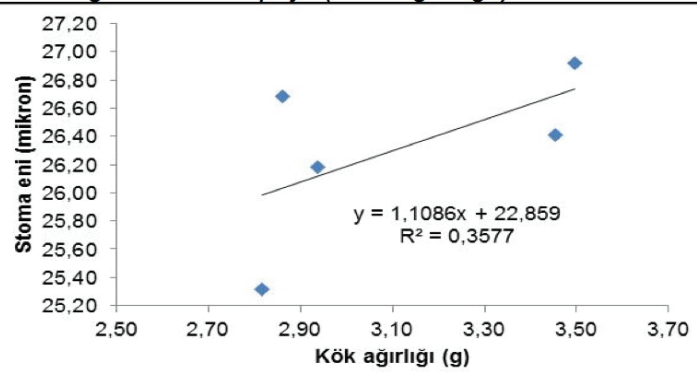

Kök ağırlığı ve stoma eni

Root weight and stomata width

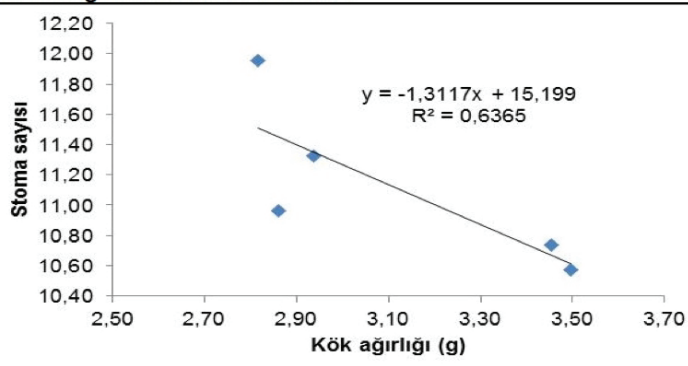

Kök ağırlığı ve stoma sayısı

Root weight and stomata number

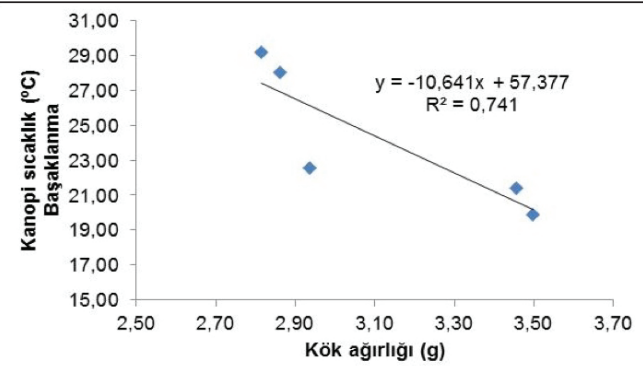

Kök ağırı ı̆ı ve kanopi sıcaklığı $\left(^{\circ} \mathrm{C}\right.$ ) (başaklanma dönemi)

Root weight and canopy temperature (heading stage)

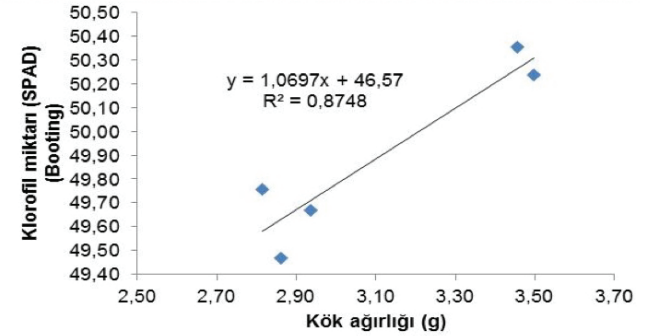

Kök ağırlığı ve klorofil (SPAD) (Sapa kalkma) Root weight and chlorophyll (shooting stage)

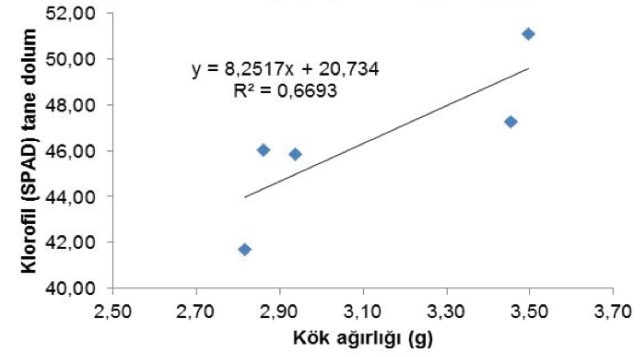

Kök ağırlı̆ı ve klorofil (SPAD) (Tane dolum) Root weight and chlorophyll (grain filling stage)

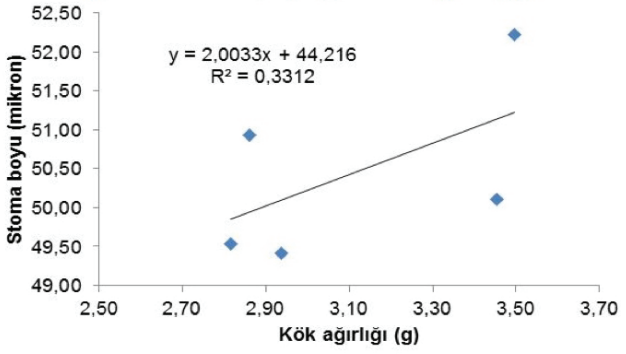

Kök ağırığı ve stoma boyu

Root weight and stomata length

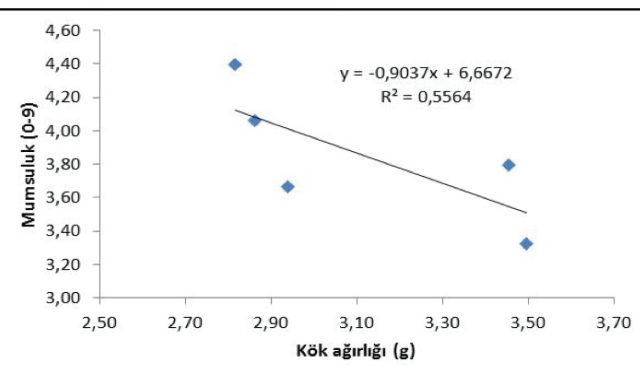

Kök ağırlığı ve mumsuluk Root weight and gloucousity

Șekil 1. Farklı kuraklık uygulamasında kök ağırlığı ile bazı fizyolojik karakterler arasında ilișkiler

Figure 1. The comparison of the root weight and some physiological characters under various drought stress 
Çizelge 4. Farklı bitki gelișme dönemlerindeki kuraklığa göre kök ağırlığı ile bazı fizyolojik karakterler arasındaki korelasyon katsayıları

Table 4. Correlation coefficient among root weight and some physiological characters under various drought stress condition

\begin{tabular}{|c|c|c|c|c|c|}
\hline \multirow{2}{*}{ Karakterler } & \multicolumn{5}{|c|}{ Uygulama konuları } \\
\hline & KÖK (KS1) & KÖK (KS2) & KÖK (KS3) & KÖK (KS4) & KÖK (KS5) \\
\hline BGS & $-0.657^{\star *}$ & $-0.449^{\star \star}$ & -0.106 & $-0.323^{\star \star}$ & $-0.327^{\star \star}$ \\
\hline OGS & $-0.751^{\star \star}$ & $-0.536^{\star \star}$ & $-0.229^{*}$ & $-0.388^{\star \star}$ & $-0.410^{\star \star}$ \\
\hline TDS & $-0.308^{\star \star}$ & $-0.245^{\star}$ & $-0.350^{\star \star}$ & -0.072 & -0.030 \\
\hline MUM & 0.178 & $0.248^{*}$ & 0.156 & 0.092 & 0.180 \\
\hline STS & 0.057 & -0.171 & $-0.210^{*}$ & -0.023 & 0.087 \\
\hline STE & 0.169 & -0.033 & 0.047 & $0.272^{\star \star}$ & 0.129 \\
\hline STB & $-0.285^{\star \star}$ & 0.100 & 0.165 & -0.044 & $-0.210^{*}$ \\
\hline $\mathrm{CHB}$ & $0.407^{\star \star}$ & $0.234^{*}$ & $0.251^{*}$ & $0.373^{\star \star}$ & 0.113 \\
\hline $\mathrm{CHH}$ & $-0.286^{\star \star}$ & -0.094 & -0.117 & 0.066 & -0.149 \\
\hline CHGF & $0.326^{\star \star}$ & $0.613^{\star \star}$ & $0.396^{\star \star}$ & $0.468^{\star \star}$ & $0.217^{\star}$ \\
\hline СТВ & -0.074 & -0.101 & 0.042 & $-0.302^{\star *}$ & $-0.227^{\star}$ \\
\hline $\mathrm{CTH}$ & $-0.259^{\star}$ & $-0.580^{\star *}$ & $-0.340^{\star *}$ & -0.104 & $-0.318^{\star \star}$ \\
\hline CTGF & $-0.362^{\star \star}$ & $-0.427^{\star \star}$ & -0.140 & $-0.413^{\star *}$ & $-0.393^{\star \star}$ \\
\hline
\end{tabular}

Not: ${ }^{* \star} \mathrm{P}<0.01$; ${ }^{*} \mathrm{P}<0.05$, KS: Kuraklık stresi, BGS: Bașaklanma gün sayısı, OGS: Olgunlașma gün sayıs, TDS: Tane dolum süresi, MUM: Mumsuluk, STS: Stoma sayıSı, STE: Stoma eni $(\mu)$, STU: Stoma boyu ( $\mu$ ), CHB: Bașaklanma öncesi klorofil, CHH: Bașaklanma dönemi klorofil, CHGF: Tane dolum dönemi klorofil, CTB: Bașaklanma öncesi kanopi sıcaklığı, CTH: Bașaklanma dönemi kanopi sıcaklığı, CTGF: Tane dolum dönemi kanopi sıcaklığı

Note: ${ }^{* *} P<0.01{ }^{*} P<0.05$; KÖK: root weight (g), KS: Drought stress, BGS: Days of heading, OGS: Days of maturity, TDS: Days of grain filling, MUM: Gloucousity (1-9), STS: Stomata number, STE: Stomata width, STU: Stomata length, CHB: Chlorophyll at booting stage, CHH: Chlorophyll at heading, CHGF: Chlorophyll at grain filling, CTB: Canopy temperature at booting, CTH: Canopy temperature at heading, CTGF: Canopy temperature at grain filling

artması dolayısı ile kuraklık ile mumsuluk arasında olumsuz ilișki belirlenmiștir. Bu sonuç mumsuluk oranı için genotip ve çevre koșullarının birlikte etki ettiği, mumsuluk yönünden genotip ve çevre koșullarının birlikte değerlendirilmesi sonucuna ulașılmıștır.

Mumsu yapıya sahip çeșitlerin, mumsuzlara göre daha fazla biyolojik ve tane verimine sahip olduğu (Dakheel ve Makdis 1991), kurağa dayanıklı bitkiler, kurak koșullara uyum sağlamak için yaprak mumsuluk oranını artırması gibi bazı fizyolojik özellikleri içerdiği (Kalaycı ve ark. 1998), kuraklığa toleransta bitkilerde yaprak mumsuluğu değerlendirilmesi gereken önemli özelliklerden (Dencic ve ark. 2000) olduğunu belirten araștırmacıların bulgularını bu çalıșmada da görmek mümkün olmuștur. Mumsuluk oranı yönünden genotipler arasında önemli varyasyon olduğu en fazla mumsuluk 8.9 oranı ile BBVD7 hattında belirlenirken, mumsuluğu en düșük Tekirdağ, EBVD24-07 ve Golia çeșitleri olmuștur.

Genotiplere göre ölçüm yapılan üç bitki gelișme döneminde de en düșük kanopi sıcaklığı Kate A-1 çeșidinde ölçülmüș olup bu çeșidin yüksek verim potansiyeline sahip olması kanopi sıcaklığı ile verim arasındaki ilișkiyi doğrulamıștır. Araștırmada mumsuluk oranı en yüksek olan BBVD7 hattı, Kate A-1 çeșidinden sonra düșük kanopi sıcaklığı ölçülen diğer bir genotip olmuștur. Genotiplerde yapraklarda mumsuluk oranının artıșı kanopi sıcaklığını düșürmüștür (Çizelge 4). En yüksek kanopi sıcaklıkları ise Golia ve Tekirdağ çeșitlerinde ölçülmüștür. Her iki çeșidin mumsuz ve açık yaprak rengine sahip olmaları kanopi sıcaklığının yaprak rengi ve mumsuluk oranı ile ilișkisini göstermiștir.

\section{Kök ağırlığı ile fizyolojik parametreler arası ilișkiler:}

Araștırmada farklı gelișme dönemlerinde kuraklık uygulamasında kök ağırlığı ile bazı karakterler arasındaki ikili ilișkiler incelenmiștir. Șekil 1'de görüldüğü gibi kanopi sıcaklığı ile kök ağırığı arasında bașaklanma öncesi $\left(r^{2}=-0.783, n=5\right)$ ve bașaklanma dönemi $\left(r^{2}=-0.741, n=5\right)$ ve tane dolum dönemlerinde $\left(r^{2}=-0.768, n=5\right)$ olumsuz ilișki belirlenmiștir. Kanopi sıcaklığının tane verimi ile de olumsuz ilișkili olması bu ilișkiyi doğrulamaktadır. 
Bitkide kök miktarının daha fazla olması bitkiye daha fazla su tașınacağı ve bu sonucun bitki kanopisinin daha serin olacağı sonucu ölçülen kanopi sıcaklığına da yansımıștır.

Genotiplerde kök ağırlığı ile bașaklanma öncesi, bașaklanma dönemi ve tane dolum dönemlerinde ölçülen klorofil kapsamı arasında olumlu ilișki belirlenmiștir. Kök ağırlığı ile klorofil kapsamı bașaklanma öncesi $\left(r^{2}=0.874, n=5\right)$ ve bașaklanma dönemi $\left(r^{2}=0.314, n=5\right)$ ve tane dolum dönemlerinde $\left(r^{2}=0.669, n=5\right)$ olumlu ve farklı oranlarda ilișki saptanmıștır. Bitkide kök miktarının artıșı bayrak yaprakta ölçüm yapılan klorofil kapsamını artırmıș özellikle bașaklanma dönemi öncesi ile tane dolum döneminde kök miktarının yaprakta klorofil kapsamının artıșına daha fazla katkı yaptığı görülmüștür (Şekil 1).

Kök ağırlığı ile stoma yapısı karșılaștırıldığında stoma eni ve stoma boyu ile düșük oranda olumlu ilișki içerisinde olduğu görülmüștür. Bu sonuç kök miktarı arttıkça daha fazla su alması ve dolayısı ile stoma hacminin de arttığı yorumu yapılmıștır. Bitkide kök miktarı stoma hacmini olumlu yönde etkilerken stoma sayısı ile olumsuz $\left(r^{2}=-0.636, n=5\right)$ yönde ilișkili olduğu belirlenmiștir.

Ekmeklik buğdayda çeșitlerde mumsuluk özellikle kurak koșullarda daha öne çıkan bir karakter olup, mumsu yapıya sahip çeșitlerin, mumsuzlara göre daha fazla biyolojik verim ve tane verimine sahip olduğu (Dakheel ve Makdis 1991), kurağa dayanıklı bitkiler, kurak koșullara uyum sağlamak için yaprak mumsuluk oranını artırması gibi bazı fizyolojik özellikleri içerdiği (Kalaycı ve ark., 1998) yapılan çalıșmalarda görülmüștür. Beș farklı seviyede uygulamanın yer aldığı bu çalıșmada genotiplerde kök miktarının kurak koșullarda azalması ve mumsuluk oranının artmasından dolayı mumsuluk ile olumsuz yönde ilișkili olduğu belirlenmiștir ( $\left.r^{2}=-0.556, n=5\right)$ (Şekil 1).

Araștırmada genotiplerde kök ağırığı ile incelenen karakterler arasında farklı gelișme dönemlerine göre korelasyon katsayıları belirlenmiș ve Çizelge 4'te verilmiștir. Erken dönem kuraklık uygulamasında (KS1) bitkide kök miktarının bașaklanma gün sayısı $\left(r=-0.657^{\star \star}\right)$, olgunlașma gün sayısı $\left(r=-0.751^{\star \star}\right)$ ve tane dolum süresi $\left(r=-0.308^{\star *}\right)$ ile arasında olumsuz ilișkili olduğu görülmüș olup kök miktarındaki artıș genotiplerde olgunlașma ve tane dolum süresinin uzamasına neden olmuștur. Benzer ilișki bașaklanma ile fizyolojik olum dönemleri arasında uygulanan kuraklıkta da azalarak görülmüștür. Kuraklık stresi uygulanmayan (KS3) koșullarda ise bu ilișkinin daha azaldığı belirlenmiștir. Doğal uygulama ile tam kuraklık uygulamalarında da yakın ilișki olması kök miktarının özellikle bitkide sapa kalkma döneminden bașaklanma dönemine kadar olan dönemde diğer dönemlere göre daha önem arz ettiği belirlenmiștir. Bitkide mumsuluk ile kök miktarı arasında sadece geç dönem kuraklıkta (KS2) önemli ve olumlu ilișki $\left(r=0.248^{*}\right)$ belirlenirken diğer gelișme dönemleri ve kuraklık uygulamalarında herhangi bir etkileșim bulunmamıștır. Sapa kalkma döneminde ve tane dolum süresinde bayrak yaprakta ölçümü yapılan klorofil miktarı bitkilerde kök miktarı ile yüksek oranda ilișkili olduğu görülmüștür.

Sapa kalkma dönemindeyapılan ölçümlerde korelasyon katsayıları; erken dönem kuraklık uygulanan ana parselde kök miktarı ile klorofil miktarı arasında $r=0.407^{\star *}$, geç dönem kuraklık uygulanan ana parsellerde $r=0.234^{*}$, kuraklık stresi uygulanmayan ana parsellerde $r=0.251^{*}$ ve doğal parsellerde $r=0.373^{\star *}$ katsayıları saptanmıștır. Stres koșullarının çok yüksek olduğu tam kurak koșullarda ise herhangi bir ilișki görülmemiștir. Araștırmada tane dolum döneminde beș farklı uygulamada klorofil kapsamı ölçümü yapılmıștır. Belirlenen korelasyon katsayıları; sapa kalkma döneminde kuraklık uygulanan parsellerde $r=0.326^{\star \star}$, geç dönem kuraklık uygulanan parsellerde $r=0.613^{\star \star}$, kuraklık uygulanmayan koșullarda $r=0.396^{\star \star}$ olurken doğal parsellerde $r=0.468^{\star \star}$ ve tam kuraklık uygulanan parsellerde $r=0.217$ olarak belirlenmiștir. Bu sonuçlar tane dolum döneminde kök miktarının yapraklardaki klorofil kapsamının artıșına önceki bitki gelișme dönemlerine göre daha fazla etki ettiğini göstermiștir. Ayrıca geç dönem kuraklık stresi uygulanan koșullarda kök miktarındaki artıș bayrak yapraktaki klorofil miktarını daha fazla artırdığı belirlenmiștir (Çizelge 4).

Kurağa dayanıklılıkta genotiplerde düșük kanopi sıcaklığı önemli bir fizyolojik parametre olup verim ile negatif ilișkili olduğu birçok araștırmacı tarafından açıklanmıștır (Reynolds ve ark., 2000; Blum, 2009). Araștırmada 
erken dönem geç dönem ve tam kuraklık uygulamalarında kök miktarı başaklanma dönemi ile tane dolum dönemlerinde kanopi sıcaklığını önemli oranda düşürmüştür. Bașaklanma döneminde yapılan ölçümlerde tespit edilen korelasyon katsayıları sırasıyla KS1'de $r=-0.259^{*}$, KS2'de $r=-0.580^{\star *}$, KS3'te $r=-0.340^{\star *}$ ve KS5'te $r=-0.318^{\star *}$ olarak belirlenmiștir. Tane dolum döneminde uygulama konularına göre yapılan ölçümlerde belirlenen korelasyon katsayıları ise sırasıyla KS1'de $r=-0.362^{\star \star}$, K2'de $r=-0.427^{\star \star}$, KS3'te önemsiz, KS4'te $r=-0.413^{\star *}$ ve KS5'te $r=-$ $0.393^{\star *}$ olarak belirlenmiștir. Bașaklanma ve tane dolum döneminde belirlenen bu ölçüm sonuçları kök miktarının fazla olması bitki gelișme dönemlerinin ileri devresinde genotiplerde kanopi sıcaklığını daha düșük seviyede tutmasına neden olmuștur.

\section{Sonuç}

Kurağa dayanıklııkta bitkilerde kök yapısı çok önemli bir karakter olup kök miktarı ve kök uzunluğu genotip ve çevre koșullarına göre değișkenlik göstermiștir. Araștırmada incelenen genotipler arasında en fazla kök ağırlığı Bereket çeșidinde belirlenirken, en düșük ağırlık Tekirdağ çeșidinde tespit edilmiștir. Genotiplerde kök miktarının artıșı bitkilerde fotosentez için önemli unsurlardan olan klorofil kapsamının artıșına katkı sağladığı belirlenmiștir. Bayrak yapraklarda ölçülen klorofil miktarı bașaklanma öncesi ve tane dolum döneminde kök miktarı artıșı ile arttığı görülmüștür. Bu sonuçlar tane dolum döneminde kök miktarının yapraklardaki klorofil kapsamının artıșına önceki bitki gelișme dönemlerine göre daha fazla etki ettiğini göstermiștir. Ayrıca geç dönem kuraklık stresi uygulanan koșullarda kök miktarındaki artıș bayrak yapraktaki klorofil miktarını daha fazla artırdığı belirlenmiștir. Kuraklık stresi altında düșük kanopi sıcaklığı genotiplerin kuraklık stresine dayanıklılığında önemli fizyolojik göstergelerden biridir. Bitki örtüsü sıcaklığının bitki kök aksamı ile yüksek oranda ilișkili olduğu görülmüș olup, bitkilerde kök miktarı arttıkça bitki örtüsü sıcaklığında azalma olduğu tespit edilmiștir. Genotiplerde kök miktarının fazla olması bitki gelişme dönemlerinin ileri gelişme dönemlerinde kanopi sıcaklığını daha düşük seviyede tutmasına katkı yapmıştır. Bu sonuçlar kök miktarının kurağa dayanıklııkta önemli bir unsur olduğu bitki toprak üstü aksamının birçok agronomik özelliklerine farklı șekilde etkisinin yanında olgunlașma, stoma yapısı, klorofil kapsamı ve kanopi sıcaklığı gibi birçok fizyolojik özellikleri de farklı șekilde etkilediğini göstermiștir. Araștırma sonucu incelenen fizyolojik parametrelerin ekmeklik buğday genotiplerinde kök miktarının tahmin edilmesinde kullanılabileceğini göstermiștir.

\section{Kaynaklar}

Adda A., Sahnoune M., Kaid-Harch M. and Othmane Merah O., (2005). Impact of water deficit intensity on durum wheat seminal roots. Plant Biology and Pathology. C. R. Biologies 328, France.

Amani I., Fischer R.A. and Reynolds M.P., (1996) Evaluation of canopy temperature as a screening tool for heat tolerance in spring wheat. Journal of Agronomy and Crop Science 176, 119-129.

Ayeneh A., van Ginkel M., Reynolds M.P. and Ammar K., (2002). Comparison of leaf, spike, peduncle and canopy temperature depression in wheat under heat stress. Field Crops Research 79 (2-3), 173-184.

Babar M.A., Reynolds M.P., van Ginkel M., Klatt A.R., Raun W.R. and Stone M.L., (2006). Spectral reflectance to estimate genetic variation for inseason biomass, leaf chlorophyll and canopy temperature in wheat. Crop Science 46, 10461057.

Blum, A. (2009). Effective use of water (EUW) and not water-use efficiency (WUE) is the target of crop yield improvement under drought stress. Field Crops Research, 112(2-3), 119-123.

Dakheel A. and Makdis F., (1991). The Role of Glaucousness as a Selection Criterion for Drought Tolerance in Durum Wheat. Cereal Improvement Program. Annual Report, 120121. ICARDA, Aleppo.

Dencic S., Kastori R., Kobiljski B. and Duggan B., (2000). Evaluation of grain yield and its components in wheat cultivars and landraces under near optimal and drought conditions. Euphytica 113, 43-52.

Dhanda S.S., Sethi G.S. and Behl R.K., (2004). Indices of drought tolerance in wheat genotypes at early stages of plant growth. Journal of Agronomy crop Sci., 190(1)6-12.

Elizabeth A.A. and Alistair R., (2007). The response of photosynthesis and stomatal conductance to rising (CO): mechanisms and environmental interactions. Plant Cell and Environ. 30, 258270.

Fischer R.A., (2007). Understanding the physiological basis of yield potential in wheat. Journal of Agricultural Science 145, 99-113. 
Fischer, R. A. (2001). Selection Traits for Improving Yield Potantial. Application of Physiology in Wheat Breeding. Eds.: Reynolds. Chapter-13, 148-159.

Gomez K.A. and A.A. Gomez., (1984). Statistical Procedures for Agricultural Research. $2^{\text {nd }}$ Ed. John Willey and Sons, Inc. New York. 641.

Gregory P.J., Bengough A.G., Grinev D., Schmidt S., Thomas W.T.B., Wojciechowski T. and Young I.M., (2009). Root phenomics of crops: opportuniti es and challenges. Functional Plant Biology 36, 922-929.

Hamblin A., Tennant D. and Perry M.W., (1990). The cost of stress-Dry matt er parti ti oning changes with seasonal supply of water and nitrogen to dryland wheat. Plant and Soil 122, 47-58.

Heichel G.H., (1971). Genetic control of epidermal cell and stomatal frequency in maize. Crop Science, 11, 830-832

Hoad S. P., Russel G., Kettlewell P. S. and Belshaw M., (2004). Root system management in winter wheat: practices to increase water and nitrogen use. HGCA Project Report No, 351.

Jianwu T., Paul V.B., Brent E.E., Ankur R.D. and Kenneth J.D., (2006). Sap flux-upscaled canopy transpiration, stomatal conductance and water use efficiency in an old growth forest the Great Lakes region of the United States. Journal of Geophysical Research, 111.

Kalaycı M., Özbek V., Çekiç C., Ekiz H., Keser M. and Altay F., (1998). Orta Anadolu Koșullarında Kurağa Dayanıklı Buğday Genotiplerinin Belirlenmesi ve Morfolojik ve Fizyolojik Parametrelerin Geliștirilmesi. TÜBITAK Araștırma Projesi Kesin Raporu. Anadolu Tarımsal Araștırma Enstitüsü, Eskișehir.

Kalaycı M., (2005). Örneklerle Jump Kullanımı ve Tarımsal Araștırma için Varyans Analiz Modelleri. Anadolu Tarımsal Araștırma Enst.
Müd. Yayınları, Yayın No: 21, Eskișehir.

Kinyua M.G., Njoka E.M., Gesimba R.M. and Birech R.J., (2006). Selection of drought tolerant bread wheat genotypes using root characteristics at seedling stage. International Journal of Agriculture and Rural Development. School of Agriculture and Agricultural Technology, Federal University of Technology.

Öztürk İ., Kahraman T., Avcı R., Girgin V.Ç., Așkın O.O., Așkın B., Tuna B. and Tülek A., (2016). Effect of Rainfall and Humidity During Shooting and Grain Filling Period on Yield and Quality in Bread Wheat. VII International Scientific Agriculture Symposium "Agrosym 2016" , Book of Proceeding, 1392-1400. Johorina, Bosnia and Herzegovina.

Passioura J.B., (1983). Root and drought resistance. Agricultural Water Management. 7, 265-280.

Reynolds M. P., Delgado B. M. I. (2000). Gutierre Rodriguez M., Larque-Saavedra A. Photosynthesis of wheat in a warm, irrigated environment. I. Genetic diversity and crop productivity. Field Crops Research. vol. 66, p. 37-50.

Siddique K.H.M., Belford R.K. and Tennant D., (1990). Root-shoot rati os of old and modern, tall and semidwarf wheats in a mediterranean environment. Plant and Soil 121, 89-98.

Van Noordwijk M., (1983). Functional interpretation for root densities in the field for nutrient and water uptake. Root Ecology and its Practical Application, International Symposium Gumpenstein, 207-226.

Zadoks J.C., Chang T.T. and Konzak C.F., (1974). A decimal code for growth stages of cereals. Weed Res. 14, 415-421. 